\title{
TRACK AND SECTOR IN EGYPTIAN HIGHER EDUCATION: WHO STUDIES WHERE AND WHY?
}

\author{
Fatma Abdelkhalek ${ }^{1}$ \\ Budapest University of Technology and Economics, Hungary
}

Ray Langsten

American University in Cairo, Egypt

\begin{abstract}
Following the 1952 revolution, the Egyptian higher education system grew rapidly, with post-secondary institutes complementing the expanding university system. Private post-secondary institutes were permitted from 1970; in the early 1990s financial constraints and pressures for cost recovery prompted legislation allowing private universities. In the face of expansion, diversification, and partial privatization, concerns have arisen about equity in higher education opportunities. The 2014 Survey of Young People in Egypt is used to examine correlates of higher education track placement and of sector placement within tracks. We produce secondary score and wealth profiles of students in selected fields, specific for track and sector. Analysis shows who studies where and suggests reasons why. Attending a particular track and sector in higher education is driven: 1) primarily by scores on the secondary school leaving exam; and 2) secondarily by the ability to pay for private higher education.
\end{abstract}

Keywords: Higher Education, Equity, Privatization, Diversification, Egypt

Globally, higher education, both public and private, has existed for centuries. Traditionally universities and other higher education institutions, served the elite (Schendel and McCowan 2016; Shrivastava and Shrivastava 2014). Public institutions were often tuition free; private universities were largely not-for-profit institutions (Bernasconi 2010; McCowan 2007). Following the Second World War, there was a rapid expansion of higher education in many countries (Arum, Gamoran, and Shavit 2007; Varghese and Puttmann 2011). In this same period, similar to other countries, higher

\footnotetext{
${ }^{1}$ Correspondence: Institute of Mathematics, Budapest University of Technology and Economics, Muegyetem
} rkp. 3. Budapest 1111, Hungary; Email: fatma@math.bme.hu

This paper was part of Ms. Abdelkhalek's work for the Research Methods for Young Egyptian Scholars Program focused on "Assessing Equity in Higher Education". The program was funded by the Ford Foundation. 
education in Egypt grew and diversified, and private higher education was introduced. In the newly large and diverse higher education structure of Egypt, we ask: who studies where, and why? The answer allows us to address two questions raised in the literature: 1) are the public and private sectors of Egyptian higher education distinct and separate; 2) do private universities in Egypt skim the best and wealthiest students?

In virtually every country, higher education policies are affected by economic and financial conditions (Patrinos 1990). While the post-war growth involved all types of higher education institutions, increased demand and constrained resources led higher education in many countries to undergo deregulation, diversification, and partial privatization (Akplu 2016; Arum, Gamoran, and Shavit 2007; Levy 2010; Quddus and Rashid 2000; Teixeira and Amaral 2001). Recently, in many countries, the private, forprofit, sector has been the fastest growing segment of higher education (Altbach et al. 2009; Varghese and Puttman 2011). In developing countries the shift to private education was encouraged by cost recovery programs (World Bank 1994). Private for-profit higher education is seen as "client seeking", absorbing demand not met by elite "status seeking" institutions (Arum, Gamoran, and Shavit 2007:7). Client seeking institutions focus on fields demanded by the labor market (Akplu 2016; Levy 2006; 2013). Their growth, along with the "internal privatization" that takes place when public universities charge more and higher fees (Kwiek 2016; Slantcheva-Durst 2010), has shifted the burden of higher education costs from public coffers to private purses (Carpentier 2012; McCowan 2004; Rasmussen 2006; UNESCO 2017).

Historically higher education tended to be a "unitary", elite system. But, as it has expanded, it has also diversified (Arum, Gamoran and Shavit 2007). With expansion, second tier institutions were introduced and spread. Tracking in higher education became prevalent, with academic universities complemented by more professional/vocational focused institutions (Akplu 2016; Varghese and Puttman 2011).

Increasing costs raise concerns about equity of access. Some assumed that continued expansion alone would eliminate the effect of social background on opportunities for higher education (Blossfeld and Shavit 1993; Halsey 1972). However, as early as 1980 researchers observed that, in its initial stages, expansion leads to greater inequality; only much later may it reduce inequality (Halsey, Heath and Ridge 1980). This concept was formalized as maximally maintained inequality (Raftery and Hout 1993), and extended as effectively maintained inequality (EMI): the tendency for advantaged groups to maintain differences in quality of education, even as the disadvantaged reach equality in the level of attainment (Lucas 2001). While the increased dependence on private funding magnifies inequality, the effect of privatization on expansion may leave overall inequality largely unchanged (Arum, Gamoran and Shavit 2007).

Beyond the persistence of inequality in access to higher education as a whole, there is the question of how diversification and privatization affect equality within higher education. For example, private institutions may "skim" the best and the wealthiest students, leaving less qualified, and poorer, students to public institutions (Cloete and Moja 2005; Geiger 1985; Orlans 1992). Or, to the contrary, better, wealthier students with academic backgrounds that qualify them for entrance to demanding public institutions, may leave poorer students, with lower grades, to pay for private higher education (Chivore 2006). Another concern is that wealthy students will dominate prestigious fields, leaving those from poor families to fill seats in less desirable fields. It is important to know which students attend what type of higher education institution, what fields they choose to pursue, and why they make these choices (Morley et al. 2010; Morley 2014). These questions are the focus of our research. 


\section{Evolution of Egyptian Higher Education}

While higher education in each country expands, diversifies, and privatizes in its own way, Egyptian higher education shares traits seen in other developing countries (Varghese 2006). Egyptian higher education effectively has three tracks. There are two main divisions: 1) universities, offering four to seven year academic degrees; and 2) institutes, with two tracks - a) upper-intermediate institutes, offering two year technical degrees, and b) higher institutes, giving four or five year professional degrees. Within each track, there are two sectors: public and private. Below is a detailed description of how these tracks and sectors of Egyptian higher education have evolved and grown.

Higher education in Egypt dates to the opening of the Al-Azhar University in 365 A.H. (975 C.E). Egyptian National University opened in 1908 as a private institution; in 1925 it became public, was renamed the State University, was later renamed Fuad 1, and after the 1952 revolution became Cairo University (Farag 2007; Richards 1992). In 1950, there were three public, secular universities in Egypt (Fuad 1 - Cairo, Farouk 1 - now Alexandria, and the then recently opened Ibrahim Pasha - now Ain Shams) (Ginsburg and Megahed 2011). In addition, there was Al-Azhar University, a public university that functions under a separate administrative structure, and the small, private American University in Cairo.

In the 1950s, President Gamal Abdel Nasser, concerned about national development and social equality, implemented a range of policies designed to bring economic, social and educational development (Szyliowicz 1973). In 1962 Nasser promised: 1) a universal secondary school leaving examination for admission to higher education; 2) elimination of all direct tuition fees for higher education; and 3) a government job for all higher education graduates - policies intended to increase demand for higher education. The government guaranteed all qualified secondary school graduates a place in tertiary education (Al-Ahram 1962; Antoninis 2001; Arabsheibani 1988; Barsoum 2014; Shann 1992). Nasser believed that these policies would, in themselves, result in equitable enrollment in higher education (Al-Ahram 1962).

Nassar's policies have largely been maintained. Egypt's 1971 constitution committed the state to offer free education from primary school through higher education, a guarantee reiterated in the 2014 constitution (Assaad 2010; Fahim and Sami 2011; MoE 2014). Standardized secondary school leaving exams are used to this day. Only the promise of jobs in the government bureaucracy for all higher education graduates, facing the reality of too many graduates for too few government positions, was abandoned in the late 1980s (OECD 2015). Existing national universities opened branches in the provinces of Upper Egypt and the Nile Delta. These branches grew and became independent universities. By 2017, there were 25 public universities throughout Egypt serving about 2.2 million students (CAPMAS 2017). The wide geographical distribution of universities sought to provide equitable educational opportunities and reduce internal migration of students (MoHE n.d.).

The private sector of higher education in Egypt dates to 1919 when the American University in Cairo (AUC) opened as a private non-profit institution ${ }^{2}$. In the early 1990s: 1) legislation permitted private, for-profit, universities; 2) programs were begun in the national universities charging fees for language sections and other special courses ${ }^{3}$ (Fahim and Sami 2011; Radwan, Ibrahim and Sharaf 2012). These actions were driven by an Economic Reform and Structural Adjustment Program designed to shift the economic burden of higher education from relying solely on the public sector toward private sector

\footnotetext{
${ }^{2}$ AUC remains the only non-profit private university in Egypt. About 5 percent of all private university students in Egypt attend AUC.

${ }_{3}$ There are no scholarships, or other government financial support, available for studying in these special sections of the national universities.
} 
participation (Megahed 2002; Richards 1992). Responding to the 1990 decree, four new private for-profit universities opened in 1996. Since this small beginning, private universities and their student bodies have expanded rapidly. By 2017, more than 138 thousand students were studying in 22 private universities (CAPMAS 2017). Despite this growth, private universities enroll only about 6 percent of all university students.

In 1956, training centers offering technical study for students who finished secondary school were introduced. In 1966/1967, these centers were developed into the two year upper-intermediate institutes for industrial and commercial technicians. Later, new specializations were introduced. Initially all institutes were in the public sector. In 2007, there were 45 public upper-intermediate institutes grouped into 8 technological colleges (MoHE n.d). In 2017 these technological colleges had 112 thousand students (CAPMAS 2017). As early as 1970, policy makers sought ways to increase higher education places without increasing the government education budget. In response the government issued law 1970/52 establishing private higher and upper-intermediate institutes in all governorates (MoHE n.d.). A 2017 report identifies only 5 private technological colleges with 45,311 students in the academic year 2015/2016 (CAPMAS 2017).

In 1963 the Ministry of Higher Education established a number of higher industrial, agricultural, and commercial institutes. As the demand for professional education increased, higher institutes expanded rapidly. After passage of law 1970/52, private higher institutes were permitted to offer courses in such fields as social services, administration, secretarial skills, and computer (MoHE n.d.; MoHE 2007). In the academic year 2014/2015, the number of higher institutes' graduates (both public and private) was more than 66 thousand (CAPMAS 2017)4.

\section{Access to Egyptian Higher Education}

Tracking in secondary school is a key determinant of access to higher education (Cupito and Langsten 2011; Langsten 2015). At the time of the 1952 revolution, almost all secondary students (around 95\%) were enrolled in the general (academic) secondary track (Richards 1992; Szyliowicz 1973). As secondary education expanded, technical/vocational $(\mathrm{T} / \mathrm{V})$ secondary grew more rapidly. Initially this was in response to Nasser's policies requiring educated technicians for the industrialization of Egypt (Elgeziri and Langsten 2011). Later, the government also realized that it could not afford university education for all secondary graduates. Policy makers sought to decrease the burden on universities by diverting students from general/academic education to $\mathrm{T} / \mathrm{V}$ secondary (Megahed 2002; Richards 1992). By the early 2000s, this effort had succeeded. While almost all general secondary graduates continued to higher education, T/V secondary had effectively become a terminal degree with more than $90 \%$ of $\mathrm{T} / \mathrm{V}$ secondary students ending their formal education upon graduation (Langsten 2015).

In Egypt, tracking in secondary follows the European model where $\mathrm{T} / \mathrm{V}$ secondary schools are separate from schools offering an academic curriculum (Tieban and

\footnotetext{
${ }^{4}$ This is the most recent data available. CAPMAS data and the publications of the MoHE give contradictory information about the number of public and private institutes, and the number of students who attend them. For higher institutes, government documents do not separate the public and private sectors. One source, using data from the 2009 Survey of Young People in Egypt (SYPE), states that $98.9 \%$ of all young people 20-29 years of age who attended higher institutes attended private higher institutes (Krafft, Elbadawy, and Assaad 2013). This figure is inconsistent with the distribution of public and private higher institute students in the 2014 SYPE data we use. Also, note that the Statistical Yearbook presents the number of students for upper-intermediate institutes, but the number of graduates for higher institutes. A figure of 66 thousand graduates of higher institutes implies perhaps 250-300 thousand students, about twice the total number of upper-intermediate students. SYPE data, on the other hand, show approximately the same number of students in the two types of institute. We are unable to resolve the inconsistencies between sources, and have simply presented the SYPE data as we find them.
} 
Wolbers 2010). Secondary tracking is based on: 1) the score on the leaving exam at the end of preparatory (middle) school; and 2) for some students, their, and/or their family's, aspirations (Cupito and Langsten 2011; Elgeziri and Langsten 2011). Aspirations come into play when a student's family's ability and willingness to pay the private tutoring and other monetary and psychological costs of general secondary, as well as the anticipated direct- and opportunity-costs of higher education cause students who qualify for general secondary to pursue T/V secondary instead (Elgeziri and Langsten 2011). Secondary track placement is highly correlated with family wealth. Among children from the wealthiest one-fifth of families, about $75 \%$ study in the general secondary track, the natural path to higher education; among children from families in the poorest quintile, only about 20\% do so (Cupito and Langsten 2011). This diversion of poor children into the lower quality $\mathrm{T} / \mathrm{V}$ secondary, while the wealthy pursue general secondary education is consistent with EMI (Jackson and Buckner 2016; Langsten 2015).

A student's track and field of study in higher education depends largely on the student's score on the examination at the end of secondary school (the Thanaweya Amma $[\mathrm{TA}]^{5}$ for the general track, and Shahda exam for the T/V track) (World Bank 2010). In Egypt, the university system is based on "faculties", while institutes have departments. The coordination office (mektab el-tansik) of the Ministry of Higher Education controls the minimum acceptable scores required to study in a particular faculty or department at all higher education institutions ${ }^{6}$. There can be large minimum score differences across tracks and sectors to study in effectively the same faculty or department.

Within a particular university the minimum TA score required to study in a prestigious faculty (generally in the range of 97 or higher) will be higher than the score necessary to study in a faculty that is less prestigious, with the least prestigious faculties requiring a score of about 70 . Students who wish to enter higher education complete a "preferences" form on which they list the institution and faculty/department where they would like to study. Students may list relatively prestigious faculties at public universities first (Barsoum 2017). Students whose grades are not high enough to study their field of choice at a public university, but who come from a family that can afford to pay tuition, may choose to enter a private university that will accept a lower score to study in the chosen field (Barsoum 2017; Faek and Lynch 2015; Krafft and Alawode 2018; Krafft, Elbadawy, and Assaad 2013).

When considering fields of study, rather than faculties, the situation becomes complex because some fields of study are located in different faculties in different universities. For instance, statistics is sometimes a branch in the high-prestige Faculty of Science, sometimes in the relatively low-prestige Faculty of Commerce, or at Cairo University it is in the highly prestigious Faculty of Economics and Political Science. Similar differences can occur with economics, computer science, or other fields.

Even those with a very low score on the TA, below the minimum accepted by any university, may go to an upper-intermediate or higher institute if they choose. Students in $\mathrm{T} / \mathrm{V}$ secondary must obtain a very high score on the Shahda, and then successfully complete a short-course (Moadla), to qualify for only certain faculties at university. Students with even a minimum score in $\mathrm{T} / \mathrm{V}$ secondary can join either upper-intermediate or higher institutes. In general, the minimum score required to study a given field at a higher institute is lower, sometimes much lower, than the score required to study the

\footnotetext{
${ }^{5}$ The TA consists of a series of exams on core subjects. The actual score is the sum of points earned. The total number of possible points is generally around 410. The score people speak of is the percentage of the total points earned. Thus, someone who earned 369 points will have a score of $90 \%$. Following common usage, and in order to avoid the overuse of \% signs, when we speak of TA scores, we will use the percentages, but drop the \% sign, and speak, for example, of a score of 90. For additional information about the TA see: (https://en.wikipedia.org/wiki/Thanaweya_Amma).

${ }^{6}$ A description of the tansik system is in Appendix A.
} 
same field at a university (see Appendix A, Table A1). Scores required to study at an upper-intermediate institute are even lower.

Thus, a high score on the TA allows students to enter any field in any track or sector, according to their preference. Students with a low score on the TA may still qualify for university, but will be accepted by only a few faculties, and thus will be able to study only specific fields. Those with very low scores can continue to higher education, but perhaps only in a higher, or upper-intermediate, institute.

Previous work shows that among general secondary graduates, around 95\% continue on to higher education; around $90 \%$ of $\mathrm{T} / \mathrm{V}$ secondary graduates end their educational career with their secondary degree (Langsten 2015). Although, in principle, access to higher education is based on merit, given the strong correlation between wealth and secondary track, combined with the strong effect of secondary track on progression to higher education, inevitably, there is substantial socio-economic inequality in access to higher education, despite Nasser's purportedly egalitarian policies (Krafft and Alawode 2018). In addition to wealth and secondary leaving exam scores, gender and region are also said to play important roles in access to higher education (Assaad 2010; Cupito and Langsten 2011). The percentage of females among higher education students has increased steadily from just $7 \%$ in the early 1950 s to about $50 \%$ now (Abdalla and Langsten 2016; Fahim and Sami 2011). Most higher education institutions are in urban areas. Thus enrollment in higher education is much greater in cities than in rural areas (Buckner 2013; Fahim and Sami 2011; Radwan, Ibrahim, and Sharaf 2012).

Although public education is tuition free, there are other costs involved in higher education. These include transportation, private tutoring, books, supplies, and clothing. Each year, the Egyptian government provides a limited number of scholarships for poor students who do well on the TA, to cover these ancillary costs (Fahim and Sami 2011). The non-profit American University in Cairo offers a range of scholarships, some of which benefit poor students. Some of the other private universities also offer scholarships. However, since these other private universities are for-profit institutions, it is assumed that the opportunities for financial support are limited. There are no government programs available to provide funding to study at private universities. Richards has observed: "It is widely assumed that any scholarship system would in practice reward the well-connected, rather than the talented-but-poor" (1992:20). Therefore, some argue that privatization of higher education increases inequality of opportunity. Some are concerned that private institutions skim the best students, offering admission only to "students from high socio-economic backgrounds" (Buckner 2013; Fahim and Sami 2011:60). Whatever the effects of privatization, existing research shows that access to higher education remains highly unequal (Cupito and Langsten 2011; Langsten 2015).

Different tracks and sectors serve different needs. Public universities offer a wide range of academic subjects. Private universities offer a narrower range of fields, focusing on those required by the labor market, that are popular with students (Assaad, Badawy, and Krafft 2016). Professional and technical education is clearly targeted at the labor market; this is particularly true of the private institutes. As a result, institutions in different tracks and sectors offer a different mix of fields of study. We address the specific question: are the differences seen between the different tracks and sectors due to the different mix of fields of study offered, or do they result from students who want to study a specific field, but with a secondary leaving score too low to enter a given institution, choosing to attend a different track or sector that will accept the score achieved? 


\section{Data and Methods}

We use weighted data from the 2014 Survey of Young People in Egypt (SYPE) 7 , a nationally representative survey of Egyptian youth conducted by the Population Council in collaboration with the Egyptian Cabinet Information and Decision Support Center, to investigate track and sector (public/private) in Egyptian higher education, focusing on the questions of who studies where and why. We first select young people 20-29 years of age to analyze transitions to higher education. These young adults are old enough to have completed secondary school and either entered higher, or left, education. We then narrow our sample to those who made the transition to higher education. Choices of track and sector reflect current behavior as well as can be done with survey data. We use descriptive statistics (contingency tables/percent distributions) and multivariate analysis (logistic regression) to examine our research questions.

We first test the findings of previous studies related to the transition from secondary to post-secondary education. However, our analysis focuses on inequality within Egyptian higher education, across tracks and sectors. To what degree do different types of students pursue university rather than professional or vocational higher education? Within tracks, we assess whether private universities skim the wealthiest and best qualified students. Or, do those wealthy students who score well on the TA prefer public sector institutions? Finally, we show that different fields of study predominate in different tracks and sectors. We ask: do tracks and sectors appear different because of the different fields of study they offer? Or, do they differ because they accept students with different qualifications into the same field of study? Examination of two common fields helps us understand the reasons students choose their particular track and sector. Together, these analyses offer preliminary answers to two questions. Has the growth, diversification, and partial privatization of Egyptian higher education: 1) produced two separate sectors governed by two distinct logics of admission (Buckner 2013); 2) resulted in the skimming of the best and wealthiest students into private institutions (Fahim and Sami 2011)?

\section{Results}

\section{Transition from Secondary to Higher Education}

Data show that among the 3,788 individuals aged 20-29 who completed secondary education, most students $(60 \%)$ had been in the $\mathrm{T} / \mathrm{V}$ track, while only $40 \%$ graduated from general secondary. Among those who studied T/V secondary, 91\% stopped after obtaining this degree. Just $9 \%$ continued to higher education: $4 \%$ to an upper-intermediate institute, $2 \%$ to a higher institute, and $3 \%$ to university. Among those who went to general secondary, the percentage continuing their education is inverted; $92 \%$ enter higher education: mostly to university ( $78 \%$ of all general secondary graduates), while $8 \%$ go to higher institutes, and $6 \%$ to upper-intermediate institutes.

To examine the effect of secondary track and TA score on the transition to higher education we use multivariate logistic regression. After controlling for other variables, the likelihood of a $\mathrm{T} / \mathrm{V}$ secondary graduate continuing to higher education relative to a general secondary graduate is just .01: that is, a T/V secondary graduate has only $1 \%$ the chance of going to higher education as a general secondary student. All other included variables, except for secondary sector and current age, have significant effects on entering higher education (Table 1). The effects of secondary score are also striking. Those with scores in the 70s (70.0-79.9) are more than two and one-half times as likely to continue

\footnotetext{
7 The 2014 survey is described in Population Council (2015). This document explains that the weighting procedure for the 2014 survey was the same as that used in the 2009 survey, and described in Population Council (2010, Appendix C).
} 
Table 1.

Logistic regression analysis. Odds ratios of entering higher education relative to those who did not enter among those who completed secondary school.

Students' Background $\quad$ Entered Higher vs.

Characteristics

Did Not Entert

\section{Secondary Track}

General/Azhar

Technical/Vocational

$$
0.01^{* * *}
$$

\section{Secondary Sector}

\section{Public}

Private

$$
-\overline{1.74}
$$

\section{Secondary Scores}

50-69.9

$70-79.9$

$80-89.9$

$90+$

Wealth Quintiles

Poorest

Poor

Middle

Rich

Richest

\section{Gender}

\section{Male}

Female

$$
0.69^{*}
$$

Age

$$
\begin{array}{ll}
20-24 & - \\
25-29 & 0.87
\end{array}
$$

\section{Urban/Rural Residence}

Urban/Slum

Rural

\section{Constant}

$\mathbf{N}$
$2.70^{* * *}$

$8.66^{* * *}$

$13.61^{* * * *}$

1.14

1.25

$1.61^{* *}$

$3.95^{* * * *}$

$3744^{\#}$

Significance level: * $(\mathrm{p}<0.05),{ }^{*}(\mathrm{p}<0.01), * * *(\mathrm{p}<0.001)$.

Significance levels for the predictor variables are based on the Wald test. + Those who entered higher education are coded "1"; those who did not enter are coded "o".

\# The difference in the number of cases between the text and some tables results from missing data on one or more variables included in the analysis. Secondary score is the variable with the greatest amount of missing data. Many respondents reported that they "do not remember" their scores on the secondary leaving exam.

on to higher education, as those with scores in the 50 s and 60s. Those with scores in the 80 s are almost 9 times more likely, while those with scores of 90 and above are almost 14 times as likely as those with scores below 70 to enter higher education. Only young people from the wealthiest $t^{8} 40 \%$ of families are significantly more likely than young people from

8 "A proxy for household wealth has been constructed using factor analysis based on household asset 
families in the poorest quintile to have gone to higher education. In addition: females, and rural residents are significantly less likely to enter higher education than males, and people from urban or slum areas. These results are consistent with earlier reports (Cupito and Langsten 2011; Langsten 2015).

\section{Inequality Within Higher Education.}

Determinants of Higher Education Track Placement. Moving to the analysis of higher education track and sector placement we focus on the 1570 youth aged 20-29 years old who ever entered higher education. First we use bivariate analysis to present "profiles" 9 of the students in different tracks, and to test the relationship between a range of background characteristics and the higher education track attended ${ }^{10}$. We include three secondary schools characteristics - track, sector, and TA score - plus four personal characteristics - family wealth, gender, age group, and urban/rural residence. Throughout the analysis we will focus particularly on secondary scores and wealth; these are our indictors of "skimming" for the best and wealthiest students.

Bivariate analysis in Table 2 shows that all included characteristics are statistically significantly related to higher education track. For example, $94 \%$ of university students and $73 \%$ of higher institute students hold an academic secondary degree, while just about half of the students in upper-intermediate went to $\mathrm{T} / \mathrm{V}$ secondary. This reflects the importance of secondary track in determining not just entry to higher education, but also the higher education track where individuals study. Ninety percent, or more, of students entering all higher education tracks attended public secondary schools. However, higher institute students are more likely, and upperintermediate institute students less likely to have attended a private secondary school, than university students. Just $8 \%$ of university students have TA scores less than $70 ; 65 \%$ scored 80 or above. On the other hand, about two-fifths of institute students have scores less than 70 and only about one-fifth have scores of 80 or more. In sum, students in institutes, both higher and upper-intermediate, have score profiles similar to each other, and substantially lower than the TA profile of university students. Looking at wealth, it is clear that the children of poor families are under-represented in all tracks of higher education. Among university students only about 15\% come from the $40 \%$ of families in the two poorest quintiles; this percentage increases to $20 \%$ and $27 \%$ among higher and upper-intermediate institute students, respectively. Despite the increase in the percentage of poor students across tracks, it is notable that the wealth profiles of university and higher institute students are similar, while upper-intermediate students come from distinctly poorer families. The bivariate effects of gender, age, and urban/rural

ownership and housing characteristics" (Population Council 2010:7). This general approach is described in more detail in Filmer and Pritchett (2001). Throughout we have used the wealth index from the 2014 survey, even though not all 20-29 year olds will be living with their natal family, the family they most likely would have been living with when the decision to continue to higher education, or not, and other higher education related decisions, were made. In an effort to control for this effect, we ran all the analysis using the 2009 wealth index. This, of course, would be only a partial correction for any household transition effect. In the event, although there were small changes in some of the coefficients, the level of significance of the variable, and overall pattern of results were unchanged. Therefore, for simplicity, and to preserve the approximately 200 cases lost when using the 2009 wealth index, we have retained the 2014 index.

${ }_{9}$ We consider these "profiles" because the tables are percentaged across the independent variables, rather than across the dependent variable as would be standard. We have done this because given the predominance of university students (7-8 times as many respondents attended university as went to either type of institute), we feel that the profiles are more informative.

${ }^{10}$ By assessing first track, and then, separately, sector within track we do not wish to imply that students use a decision making process that follows this sequence. On the contrary, we believe that students, when deciding where to study, consider all track and sector options as part of a unified higher education system. We consider track, and then sector, separately so as to be able to properly assess the issue of skimming. 
residence on track attended are also statistically significant. We do not discuss these variables further. They are included only as control variables.

Table 2.

Percent distribution ${ }^{+}$(profiles ${ }^{+\dagger}$ ) of students' secondary school and background characteristics within each higher education track.

\begin{tabular}{|c|c|c|c|}
\hline & \multicolumn{3}{|c|}{ Higher Education Track } \\
\hline $\begin{array}{c}\text { Students' Background } \\
\text { Characteristics }\end{array}$ & University & $\begin{array}{c}\text { Higher } \\
\text { Institutes }\end{array}$ & $\begin{array}{c}\text { Upper- } \\
\text { intermediate } \\
\text { Institutes }\end{array}$ \\
\hline \multicolumn{4}{|l|}{ Secondary Track ${ }^{* * * *}$} \\
\hline General/Azhar & 94.3 & 72.6 & 51.4 \\
\hline Technical/Vocational & 5.7 & 27.4 & 48.6 \\
\hline \multicolumn{4}{|l|}{ Secondary Sector ${ }^{* *}$} \\
\hline Public & 95.3 & 91.0 & 98.9 \\
\hline Private & 4.7 & 9.0 & 1.1 \\
\hline \multicolumn{4}{|l|}{ Secondary Scores ${ }^{* * *}$} \\
\hline $50-69.9$ & 7.9 & 36.3 & 43.0 \\
\hline $70-79.9$ & 26.9 & 44.6 & 33.5 \\
\hline $80-89.9$ & 41.7 & 14.9 & 21.2 \\
\hline $90+$ & 23.4 & 4.2 & 2.2 \\
\hline \multicolumn{4}{|l|}{ Wealth Quintiles ${ }^{* * * *}$} \\
\hline Poorest & 4.8 & 6.6 & 11.5 \\
\hline Poor & 10.1 & 13.8 & 15.9 \\
\hline Middle & 13.6 & 14.4 & 17.0 \\
\hline Rich & 20.8 & 18.0 & 28.0 \\
\hline Richest & 50.6 & 47.3 & 27.5 \\
\hline \multicolumn{4}{|l|}{ Gender $^{* *}$} \\
\hline Male & 52.6 & 65.5 & 55.7 \\
\hline Female & 47.4 & 34.5 & 44.3 \\
\hline \multicolumn{4}{|l|}{ Age $^{*}$} \\
\hline $20-24$ & 58.2 & 65.5 & 53.6 \\
\hline $25-29$ & 41.8 & 34.5 & 46.4 \\
\hline \multicolumn{4}{|l|}{ Urban/Rural } \\
\hline Urban/Slum & 56.9 & 64.1 & 47.0 \\
\hline Rural & 43.1 & 35.9 & 53.0 \\
\hline $\mathbf{N}$ & 1312 & 167 & 183 \\
\hline
\end{tabular}

Significance level: * $(\mathrm{P}<0.05), * *(\mathrm{P}<0.01), * * *(\mathrm{P}<0.001)$.

Significance levels are based on the $\chi^{2}$ test.

+ For each variable we computed a cross-tabulation between that variable and higher education track.

+ We consider these "profiles" because the tables are percentaged across the independent variables, rather than across the dependent variable as would be the normal approach. We have done this because given the predominance of university students (7-8 times as many respondents attended university than went to either type of institute), we feel that the profiles are more informative. 
Table 3.

Logistic regression analysis. Pair-wise odds ratios of entering a specific higher education track relative to each of the other tracks.

\begin{tabular}{|c|c|c|c|}
\hline \multirow[b]{2}{*}{$\begin{array}{c}\text { Students' Background } \\
\text { Characteristics } \\
\end{array}$} & \multicolumn{3}{|c|}{ Higher Education Track Comparisons } \\
\hline & $\begin{array}{c}\text { University vs. } \\
\text { Higher } \\
\text { Institutes }{ }^{\dagger} \\
\end{array}$ & $\begin{array}{c}\text { University vs. } \\
\text { Upper- } \\
\text { Intermediate } \\
\text { Institutes }{ }^{+} \\
\end{array}$ & $\begin{array}{c}\text { Higher } \\
\text { Institutes vs. } \\
\text { Upper- } \\
\text { Intermediate } \\
\text { Institutes }+\uparrow+ \\
\end{array}$ \\
\hline \multicolumn{4}{|l|}{ Secondary Track } \\
\hline General/Azhar & -- & -- & -- \\
\hline Technical/Vocational & $0.17^{* * * *}$ & $0.05^{* * *}$ & $0.31^{* * *}$ \\
\hline \multicolumn{4}{|l|}{ Secondary Sector } \\
\hline Public & -- & -- & - \\
\hline Private & $0.41^{*}$ & 3.16 & $4.62^{*}$ \\
\hline \multicolumn{4}{|l|}{ Secondary Scores } \\
\hline $50-69.9$ & -- & -- & -- \\
\hline $70-79.9$ & $2.96^{* * *}$ & $7.56^{* * *}$ & $2.11^{*}$ \\
\hline $80-89.9$ & $13.98^{* * * *}$ & $17.57^{* * * *}$ & 1.17 \\
\hline $90+$ & $23.63^{* * * *}$ & $51.21^{* * * *}$ & 1.77 \\
\hline \multicolumn{4}{|l|}{ Wealth Quintiles } \\
\hline Poorest & -- & -- & -- \\
\hline Poor & 0.97 & 1.32 & 1.52 \\
\hline Middle & 1.16 & 1.88 & 1.26 \\
\hline Rich & 1.42 & 2.01 & 0.90 \\
\hline Richest & 1.09 & $2.74^{*}$ & 2.50 \\
\hline \multicolumn{4}{|l|}{ Gender } \\
\hline Male & -- & -- & - \\
\hline Female & 1.14 & 0.86 & 0.70 \\
\hline \multicolumn{4}{|l|}{ Age } \\
\hline $20-24$ & -- & -- & -- \\
\hline $25-29$ & $1.77^{*}$ & 1.17 & 0.76 \\
\hline \multicolumn{4}{|l|}{ Urban/Rural Residence } \\
\hline Urban/Slum & -- & -- & -- \\
\hline Rural & 1.03 & $0.45^{* *}$ & $0.41^{* *}$ \\
\hline Constant & 1.46 & 1.39 & 1.25 \\
\hline $\mathbf{N}$ & 1364 & 1374 & 336 \\
\hline
\end{tabular}

Significance level: * $(\mathrm{P}<0.05)$, ** $(\mathrm{P}<0.01)$, *** $(\mathrm{P}<0.001)$.

Significance levels for the predictor variables are based on the Wald test.

$\ddagger$ Column 1 of Table 3 shows the likelihood of entering university, rather than higher institutes;

Column 2 shows the likelihood of entering university rather than upper-intermediate institutes;

Column 3 shows the likelihood of entering a higher institute rather than an upper-intermediate institute.

+ Attended university is coded " 1 "; attended a higher institute is coded " 0 ".

$\uparrow+$ Attended university is coded " 1 ”; attended an upper-intermediate institute is coded "o".

$\uparrow+$ Attended a higher institute is coded " 1 "; attended an upper-intermediate institute is coded "O". 
Multivariate analysis clarifies the effects of student characteristics on track selection. Three logistic regression models ${ }^{11}$ were computed to compare the characteristics of students entering a specific higher education track relative to each of the other tracks (Table 3). That is, Column 1 of Table 3 shows the likelihood of entering university, rather than higher institutes; Column 2, the likelihood of entering university, rather than upper-intermediate institutes; Column 3, the likelihood of entering a higher, rather than an upper-intermediate, institute. To further understand the numbers presented, consider the effects of secondary track. In the first column, .17 indicates that those who studied in a T/V secondary are less than $1 / 5$ as likely as those who attended general secondary to enter university relative to higher institutes. Compared to those who studied in general secondary, $\mathrm{T} / \mathrm{V}$ secondary students are even less likely to enter university rather than an upper-intermediate institute - just 1 in 20 (0.05 - Column 2). $\mathrm{T} / \mathrm{V}$ secondary graduates are similarly only about $30 \%$ as likely as those from academic secondary to have studied in a higher rather than an upper-intermediate institute $.31-$ Column 3). Thus secondary track continues to play an important role in determining the higher education track attended, even after other variables are controlled.

As noted, in this analysis we focus on secondary scores and wealth. Look first at the comparison between university and higher institutes. Recall that students who studied in these two tracks have similar wealth profiles, but very different score profiles (Table 2). Therefore, it is not surprising that in the multivariate analysis when all variables are controlled, the effects of secondary score are strong, increasing substantially from one score level to the next, while the effects of wealth disappear (Table 3). When comparing university students with upper-intermediate students, recall that the university students had better TA scores, and come from wealthier families. Yet, again, in this comparison, the effect of secondary scores is strong, even stronger than in the previous comparison. And, critically, despite the substantial differences in wealth between these two groups, when all variables are controlled, the effects of wealth largely disappear. Only students from the wealthiest $20 \%$ of families show a relatively small, but statistically significant, increase in the likelihood of attending university rather than an upper-intermediate institute. Finally, in the comparison between students at the two types of institutes, we can see from Table 2 that those who go to higher institutes are much wealthier than those who attend upper-intermediate. But they have not translated this wealth into higher scores. Rather, these two groups have similar score profiles. In this comparison, despite the similarity in score profiles, those with scores in the 70 s are significantly more likely to study in a higher, rather than an upper-intermediate, institute. Notably, despite the wealth differences between these two groups, when controlling for other variables, wealth has no effect on the type of institute where a student studies. In sum, TA scores play a substantial role in determining the higher education track where a student studies particularly whether the student attends university or an institute - while wealth plays almost no direct role.

Some of the paired comparisons of age and urban/rural residence effects are statistically significant, while other comparisons of these variables are not. These variables, along with gender, are included only as controls.

Sector Placement within Higher Education Tracks. We now analyze the likelihood of attending a public sector university or institute, rather than a private institution, specific for each track. We created profiles of the attendees in the two sectors for each higher education track. Briefly, for universities, with the exception of age, all included variables, and notably both score and wealth, are statistically significant, with

\footnotetext{
${ }^{11}$ We have also done the analysis using multinomial regression analysis, including all three track outcomes in a single equation, and, separately, including all 6 track/sector combinations. We believe that the pairwise logistic results we present most clearly address the issues of inequality that are our main concern.
} 
students in public universities having higher grades, but coming from generally poorer households, compared to students of private universities. In each type of institute, only two variables (in neither case including either score or wealth) have a significant relationship with public/private sector, within these two tracks (Table 4).

Table 4.

Percent distribution of background characteristics of higher education by track and sector.

\begin{tabular}{|c|c|c|c|c|c|c|}
\hline \multirow[b]{2}{*}{$\begin{array}{c}\text { Background } \\
\text { Characteristics }\end{array}$} & \multicolumn{2}{|c|}{ University } & \multicolumn{2}{|c|}{ Higher Institutes } & \multicolumn{2}{|c|}{$\begin{array}{c}\text { Upper- } \\
\text { intermediate } \\
\text { Institutes }\end{array}$} \\
\hline & $\begin{array}{l}\text { Public } \\
\text { /Azhar }\end{array}$ & Private & $\begin{array}{l}\text { Public } \\
\text { /Azhar }\end{array}$ & Private & $\begin{array}{l}\text { Public } \\
\text { /Azhar }\end{array}$ & Private \\
\hline Secondary Track & \multicolumn{2}{|c|}{ **** } & & & \multicolumn{2}{|c|}{ * } \\
\hline General/Azhar & 94.9 & 85.0 & 72.0 & 73.3 & 57.4 & 31.2 \\
\hline Technical/Vocational & 5.1 & 15.0 & 28.0 & 26.7 & 42.6 & 68.8 \\
\hline Secondary Sector & \multicolumn{2}{|c|}{ *** $*$} & \multicolumn{2}{|c|}{ * } & & \\
\hline Public & 96.9 & 71.9 & 96.5 & 84.1 & 99.5 & 97.1 \\
\hline Private & 3.1 & 28.1 & 3.5 & 15.9 & .5 & 2.9 \\
\hline Secondary Scores & \multicolumn{2}{|c|}{ *** } & & & & \\
\hline $50-69.9$ & 6.9 & 23.8 & 37.7 & 35.2 & 40.7 & 49.6 \\
\hline $70-79.9$ & 26.9 & 26.5 & 42.8 & 46.8 & 31.2 & 41.5 \\
\hline 80-89.9 & 42.7 & 27.4 & 16.8 & 12.1 & 25.2 & 8.9 \\
\hline $90+$ & 23.5 & 22.4 & 2.6 & 5.9 & 2.9 & 0.0 \\
\hline Wealth Quintiles & \multicolumn{2}{|c|}{ * } & & & & \\
\hline Poorest & 5.1 & 1.0 & 6.8 & 6.4 & 12.3 & 7.7 \\
\hline Poor & 10.7 & 2.6 & 16.6 & 10.3 & 17.0 & 13.0 \\
\hline Middle & 13.5 & 15.6 & 15.1 & 13.9 & 16.1 & 20.8 \\
\hline Rich & 21.0 & 19.1 & 18.4 & 16.8 & 24.8 & 38.7 \\
\hline Richest & 49.8 & 61.8 & 43.1 & 52.5 & 29.9 & 19.9 \\
\hline Gender & \multicolumn{2}{|c|}{ ** } & & & \multicolumn{2}{|c|}{ *** } \\
\hline Male & 51.5 & 67.9 & 66.2 & 64.3 & 52.3 & 66.9 \\
\hline Female & 48.5 & 32.1 & 33.8 & 35.7 & 47.7 & 33.1 \\
\hline \multicolumn{7}{|l|}{ Age } \\
\hline $20-24$ & 58.3 & 56.1 & 57.0 & 75.7 & 55.8 & 45.3 \\
\hline $25-29$ & 41.7 & 43.9 & 43.0 & 24.3 & 44.2 & 54.7 \\
\hline Urban/Rural Residence & \multicolumn{2}{|c|}{ **** } & \multicolumn{2}{|c|}{ **** } & & \\
\hline Urban/Slum & 55.4 & 78.6 & 50.9 & 80.0 & 44.0 & 57.6 \\
\hline Rural & 44.6 & 21.4 & 49.1 & 20.0 & 56.0 & 42.4 \\
\hline $\mathrm{N}$ & 1225 & 85 & 92 & 76 & 140 & 43 \\
\hline
\end{tabular}

Significance level: * $(<0.05), * *(<0.01), * * *(<0.001)$; Significance is based on the $\chi^{2}$ test. 
We again turn to multivariate logistic regression, this time specific for each higher education track separately to examine how secondary school variables and background characteristics affect attendance at a public, rather than private, sector institution. Consider universities. Those who attended T/V secondary are less than one-fourth as likely as those who went to academic secondary to attend a public university rather than a private one.

Again, however, we are most interested in the roles of TA score and family wealth on the sector of university attended. Multivariate analysis confirms the effect of secondary score. The reference category is students in private universities. Table 5 shows that those with scores above 70 are three to almost six times more likely than those who got scores less than 70 to attend a public, rather than a private, university. As we saw for track selection, after controlling for other variables, wealth no longer has a significant effect on the likelihood of entering a public university rather than a private one. Though students from middle class and wealthier families are only about $1 / 5$ to $1 / 4$ as likely as those from the poorest families to enter public, rather than private, institutions, these effects are not statistically significant. To emphasize: even though those in private universities are generally wealthier than the students in public universities (Table 4), when other variables are controlled, the wealth effect is eliminated (Table 5). Scores, not wealth, determine access to public universities.

Turning to institutes, both the bivariate (Table 4) and multivariate (Table 5) analyses confirm that, with the exception of those with scores in the 80 s being more likely than those with scores less than 70 to enter a public upper-intermediate institute, neither of the two key variables - secondary score or wealth - has an impact on the choice of sector. For higher institutes, the only statistically significant effect shows students from rural areas being about 4 times as likely to study in a public institution as are students from urban areas. As for upper-intermediate institute students, beyond the score effect mentioned above, those who attended a $\mathrm{T} / \mathrm{V}$ secondary are about 1/5 as likely, while females are about 2.5 times more likely, to attend a public institutions, as are general secondary graduates and males, respectively. None of the other variables included has a significant effect on the sector of institute attended.

Higher Education and Field of Study. In our description of higher education in Egypt we have explained the tansik system that determines what minimum scores are required to study in specific tracks, sectors, and faculties/departments. Studying the secondary scores achieved, specific for the fields of study students enter, furthers understanding of the choices they make. As fields of study are examined in greater depth, however, it is necessary to separate universities and higher institutes from upperintermediate institutes. Upper-intermediate students are poorer, more rural, and much more likely to come from $\mathrm{T} / \mathrm{V}$ secondary than either university or higher institute students (Table 2). Moreover, these institutes grant a two-year technical diploma instead of a four- or five-year degree. The substance taught in a given field is very different in upper-intermediate institutes than it is at universities or higher institutes. In upperintermediate education, business courses focus on clerical studies, computing courses on the basic use of software packages, as opposed to the higher level skills taught in business or computing courses in universities and higher institutes. Moreover, the education provided by the upper-intermediate institutes has long been viewed as low quality (Shann 1992). Finally, the classification of the field of study in the upper-intermediate institutes is different from both universities and higher institutes (Table 6). Therefore, our detailed analysis of fields of study in different higher education tracks and sectors focuses only on these latter institutions. 
Table 5.

Logistic regression analysis. Odds ratios of entering the public sector relative to the private sector specific for each higher education track.

\begin{tabular}{|c|c|c|c|}
\hline $\begin{array}{l}\text { Background } \\
\text { characteristics }\end{array}$ & $\begin{array}{l}\text { University } \\
\text { Public vs. } \\
\text { Private }\end{array}$ & $\begin{array}{c}\text { Higher Institutes } \\
\text { Public vs. } \\
\text { Private }\end{array}$ & $\begin{array}{c}\text { Upper- } \\
\text { intermediate } \\
\text { Institutes } \\
\text { Public vs. Private }\end{array}$ \\
\hline \multicolumn{4}{|l|}{ Secondary Track } \\
\hline General/Azhar & -- & - & -- \\
\hline Technical/Vocational & $0.23^{* * *}$ & 1.27 & $0.20^{* *}$ \\
\hline \multicolumn{4}{|l|}{ Secondary Sector } \\
\hline Public & -- & -- & - \\
\hline Private & $0.10^{* * * *}$ & 0.42 & 0.30 \\
\hline \multicolumn{4}{|l|}{ Secondary Scores } \\
\hline $50-69.9$ & -- & -- & -- \\
\hline $70-79.9$ & $3.26^{* *}$ & 0.81 & 2.08 \\
\hline $80-89.9$ & $5.33^{* * * *}$ & 1.06 & $5.37^{*}$ \\
\hline $90+$ & $3.52^{* *}$ & 0.99 & $-\mathrm{a}$ \\
\hline \multicolumn{4}{|l|}{ Wealth Quintiles } \\
\hline Poorest & - & -- & -- \\
\hline Poor & 0.72 & 2.91 & 0.80 \\
\hline Middle & 0.20 & 1.38 & 0.69 \\
\hline Rich & 0.25 & 1.44 & 0.46 \\
\hline Richest & 0.21 & 1.14 & 0.95 \\
\hline \multicolumn{4}{|l|}{ Gender } \\
\hline Male & -- & -- & -- \\
\hline Female & 1.49 & 1.09 & $2.49^{*}$ \\
\hline \multicolumn{4}{|l|}{ Age } \\
\hline $20-24$ & -- & -- & -- \\
\hline $25-29$ & 1.23 & 2.14 & 0.71 \\
\hline \multicolumn{4}{|l|}{ Urban/Rural } \\
\hline Urban/Slum & -- & -- & - \\
\hline Rural & $2.12^{*}$ & $3.64^{* * *}$ & 1.14 \\
\hline Constant & 16.42 & 0.47 & 4.99 \\
\hline $\mathbf{N}$ & 1199 & 163 & 167 \\
\hline
\end{tabular}

Significance level: * $(\mathrm{P}<0.05)$, *** $(\mathrm{P}<0.01)$, *** $(\mathrm{P}<0.001)$.

Significance levels for the predictor variables are based on the Wald test.

${ }^{a}$ Empty cell; no cases.

+ For each higher education track, public institutions are coded "1"; private institutions are coded "0".

Certain fields tend to be dominant in specific tracks and sectors (Table 6). For example, education is prevalent only in public universities. The study of humanities and arts is common in public universities, but much less common in private universities and in both sectors of higher institutes. On the other hand, business administration is common in both public and private universities while being less common at private higher institutes, and much less common still in public higher institutes. Engineering/ IT is relatively common at private institutions, whether universities or higher institutes, while 
being much less common in public sector institutions, regardless of track. Services ${ }^{12}$ dominate in public higher institutes, are also found in private higher institutes, but are not common in universities (Table 6).

Table 6.

Percent distribution of fields of study by higher education track and sector.

\begin{tabular}{|c|c|c|c|c|c|c|}
\hline \multirow[b]{2}{*}{ Field of Study } & \multicolumn{2}{|c|}{ University } & \multicolumn{2}{|c|}{ Higher Institutes } & \multicolumn{2}{|c|}{$\begin{array}{c}\text { Upper- } \\
\text { Intermediate } \\
\text { Institutes }\end{array}$} \\
\hline & Public & Private & Public & Private & Public & Private \\
\hline Education \& Other & 15.6 & 0.0 & 0.0 & 0.0 & -- & ב-- \\
\hline Humanities \& Arts & 23.9 & 6.1 & 5.9 & 2.0 & -- & -- \\
\hline Social Science \& Law & 13.9 & 11.0 & 0.0 & 4.1 & -- & -- \\
\hline Business Administration & 21.2 & 21.3 & 5.0 & 13.0 & - & -- \\
\hline Scientific Fields & 11.7 & 6.5 & 7.4 & 2.5 & -- & -- \\
\hline Engineering/ IT & 8.8 & 45.6 & 18.3 & 54.3 & -- & -- \\
\hline Services ${ }^{\dagger}$ & 4.8 & 9.4 & 63.4 & 24.1 & -- & -- \\
\hline Commerce & -- & -- & -- & -- & 56.6 & 56.4 \\
\hline Industrial & -- & -- & -- & -- & 16.7 & 8.3 \\
\hline Nursing & - & -- & -- & -- & 19.4 & 0.0 \\
\hline Other & -- & -- & -- & -- & 7.3 & 35.3 \\
\hline Total & 100 & 100 & 100 & 100 & 100 & 100 \\
\hline $\mathbf{N}$ & 1194 & 82 & 83 & 72 & 125 & 38 \\
\hline
\end{tabular}

$\overline{\uparrow \text { Services are relatively low prestige fields of study, including social work, hotels and tourism, and police }}$ services.

While the mix of fields differs across tracks and sectors, in some cases, students can study the same field in different tracks and sectors. We pose two questions representing two scenarios: 1) are the differences in scores between different tracks and sectors due to the different distribution of fields of study across tracks and sectors? Or, as has been suggested, 2) do students seeking the same field of study choose the track and sector of education that will accept their secondary score? For example: consider two universities, one public, the other private. There are three fields: A (requiring a high score); B (requiring a middle score); and C (requiring only a low score). In the first scenario, the public university offers fields A (high score) and B (middle score); the private university offers only fields B (middle score) and C (low score). Thus, despite having the same requirements for the shared field, it is evident that the average score of students studying in the private university (middle plus low) will be lower than the average score in the public university (middle plus high). (See a numerical example in Appendix B, Table B1.) In our second scenario the two universities offer the same three fields. However, in this case, the scores required by the private university are lower for each of the three fields. Provided students are distributed in equal proportions across fields in the two universities, it is evident that the students in the private university will again have lower average scores than the students in the public university. (See the numerical example in Appendix B, Table B2).

${ }^{12}$ Services are relatively low prestige fields of study, including social work, hotels and tourism, and police services. 
We have already shown that the fields offered differ across tracks and sectors. It is impossible to know how much these different offerings affect average scores. However, we can examine the differences in the secondary leaving score and wealth profiles of students in two fields - business administration (BAd) and engineering/IT (IT) - across universities and higher institutes and across sectors within those tracks ${ }^{13}$ (Table 7). A finding that the average scores of students in each field differs across the tracks and sectors will lend support to the second scenario.

Table 7.

Percent distribution. Secondary score and wealth index profiles of two fields of study by higher education track and sector.

\begin{tabular}{|c|c|c|c|c|c|c|c|c|}
\hline \multirow{6}{*}{$\begin{array}{l}\text { Secondary } \\
\text { Score and } \\
\text { Wealth } \\
\text { Profile } \\
\text { Secondary } \\
\text { Score }\end{array}$} & \multicolumn{8}{|c|}{ Field of Study } \\
\hline & \multicolumn{4}{|c|}{ Business Administration ${ }^{\dagger}$} & \multicolumn{4}{|c|}{ Engineering/IT } \\
\hline & \multicolumn{2}{|c|}{ University } & \multicolumn{2}{|c|}{ Higher } & \multicolumn{2}{|c|}{ University } & \multicolumn{2}{|c|}{ Higher } \\
\hline & $\begin{array}{l}\text { Public } \\
\text { /Azhar }\end{array}$ & Private & $\begin{array}{l}\text { Public } \\
\text { /Azhar }\end{array}$ & Private & $\begin{array}{l}\text { Public } \\
\text { /Azhar }\end{array}$ & Private & $\begin{array}{l}\text { Public } \\
\text { /Azhar }\end{array}$ & Private \\
\hline & \multirow{2}{*}{\multicolumn{2}{|c|}{$* * *$}} & \multirow{2}{*}{\multicolumn{4}{|c|}{ *** $*$}} & & \\
\hline & & & & & & & & \\
\hline 50-69.9 & 6.5 & 32.2 & -- & 16.3 & 3.3 & 19.1 & 41.9 & 32.4 \\
\hline $70-79.9$ & 22.2 & 45.8 & -- & 83.7 & 7.6 & 22.4 & 40.7 & 55.9 \\
\hline $80-89.9$ & 61.0 & 22.1 & - & 0.0 & 18.3 & 26.4 & 17.3 & 8.3 \\
\hline $90+$ & 10.3 & 0.0 & - & 0.0 & 70.8 & 32.1 & 0.0 & 3.4 \\
\hline Mean & 81.3 & 70.3 & - & 73.0 & 90.8 & 79.9 & 71.6 & 71.3 \\
\hline Wealth & & & & & & & & k \\
\hline Poorest & 2.3 & 0.0 & -- & 0.0 & 0.8 & 0.0 & 0.0 & 4.2 \\
\hline Poor & 7.0 & 12.4 & -- & 10.8 & 4.6 & 0.0 & 41.0 & 11.1 \\
\hline Middle & 15.0 & 26.5 & - & 29.7 & 8.4 & 11.8 & 11.6 & 6.3 \\
\hline Rich & 19.0 & 33.2 & -- & 17.0 & 24.7 & 19.1 & 0.0 & 16.8 \\
\hline Richest & 56.5 & 27.9 & - & 42.5 & 61.5 & 69.1 & 47.4 & 61.6 \\
\hline $\mathbf{N}$ & 249 & 18 & 4 & 10 & 102 & 37 & 15 & 39 \\
\hline
\end{tabular}

Significance level: * $(\mathrm{P}<0.05), * *(\mathrm{P}<0.01), * * *(\mathrm{P}<0.001)$.

Significance levels are based on the $\chi^{2}$ test.

+ There are too few public higher institute students studying BAd (4 cases) to include them in this analysis.

Among those studying BAd, the scores skew significantly higher at public universities than at private institutions, both universities and higher institutes. (There are too few public higher institute students studying BAd [4 cases] to include them in this analysis.) The average score reflects this distribution: public university BAd students have a mean score of 81 , while the mean score of students in private universities is about 70 and about 73 for students in private higher institutes. Consideration of the wealth profiles of these BAd students in different tracks and sectors is also revealing. Public sector university students appear to be wealthier than both private university and private higher institute students, though the differences are not statistically significant ${ }^{14}$.

\footnotetext{
${ }^{13}$ Close examination of Table 6 shows that there is no field of study that has an adequate number of cases for each of the four track-sector categories. However, business administration and engineering/IT are both relatively common in all tracks and sectors. They are both considered to be market driven fields. Engineering/IT is viewed as more prestigious than business administration.

${ }^{14}$ Note that the small number of cases available for this analysis may account for the lack of statistical significance despite relatively large absolute differences in some cases.
} 
The score profiles of students studying IT - a more prestigious field, generally requiring higher scores - at public universities is statistically significantly higher than that of students at private universities (Table 7), which in turn is higher (but not significantly higher) than that of students at both public and private higher institutes. Again, the average scores reflect the differences in score profiles. The wealth profiles for IT students tell a different story than wealth does for BAd students. In the case of IT, public and private university students have similar wealth profiles, with, if anything, private university students coming from, on average, slightly (not statistically significantly) wealthier families. Among IT students in higher institutes, those attending private institutions come from statistically significantly wealthier families than do students attending public institutions.

The results clearly show that students studying in the same field have very different TA scores in the different tracks and sectors, thus supporting scenario two. The distributions of track and sector specific scores for these two fields are consistent with the overall distribution of scores for each track and sector as a whole (Table 4). The results suggest that Egyptian private universities are client-seeking, offering wealthy students the opportunity to study in the field of their interest when the TA score they achieved does not allow them to study that field at a public university. Higher institutes, whether public or private, all require lower scores. Thus the choice between studying at a public or private higher institute may depend on factors other than prestige and $\cos ^{15}$.

\section{Discussion and Conclusions}

There is persistent inequality in higher education in Egypt. Results shown in Table 1, plus earlier results for Egypt (Cupito and Langsten 201 1; Langsten 2015) and for other settings (Arum, Gamoran, and Shavit 2007; Brennan and Naidoo 2008; Halsey, Heath, and Ridge 1980; Raftery and Hout 1993) show that expansion of seats and elimination of fees for all students do not, in themselves, bring about greater equality in access to higher education - at least, not in the short run. This inequality in access to higher education in Egypt is well documented. And this inequality will persist irrespective of what is done about the public / private allocation of higher education in Egypt.

In this paper we have gone beyond the question of access, asking: within higher education, who studies in which track and sector, and why?

The bivariate results for higher education track placement conform to expectation. As we move from university to higher institutes to upper-intermediate institutes, $\mathrm{T} / \mathrm{V}$ secondary education becomes more common, secondary scores are lower, and students come from poorer families (Table 2). However, in the multivariate analysis of higher education track placement we see that secondary scores dominate the determinants of studying at university; wealth becomes insignificant. There are almost no differences between higher and upper-intermediate institute students, except the type of secondary school they attended and their urban/rural residence (Table 3). Similarly, when comparing sectors within tracks, public university students tend to have higher secondary scores, despite being slightly poorer, than private university students (Table 4). However, there is no statistically significant effect of wealth on the university sector where students study (Table 5).

Some argue that wealth plays a role because families use wealth to provide better pre-tertiary education for their children, or private tutoring to compensate for deficiencies in the educational system, and thus gain higher TA scores (Buckner 2013). No doubt, this is true. SYPE 2014 data confirm a strong correlation between wealth and TA score.

\footnotetext{
15 The quality of private higher institutes is said to be highly variable (Krafft, Elbadawy, and Assaad 2013).
} The quality of institutes available may influence the choice between public and private. 
However, while this strong correlation exists, some students from wealthy families still get low scores, while some students from poor families get high scores. In the multivariate analysis (Tables 3 and 5), after controlling for other factors, wealth has almost no impact on the choice of higher education track or sector; the best Egyptian students, in terms of their TA scores, prefer to go to public universities. Thus, in contrast to earlier literature, for both Egyptian (Fahim and Sami 2011) and non-Egyptian (Cloete and Moja 2005; Geiger 1985; Orlans 1992) higher education, these results provide no evidence that private institutions in Egypt are skimming wealthier and better qualified students. On average, students in private universities come from wealthier families than do students in public universities (Table 4). But, on average, they have lower TA scores. Given low scores, their wealth does not help them to attain a seat at a public institution.

There are two possible reasons for the differences in scores between institutions: 1) different institutions may admit students with similar scores to study in a particular field, but have a different mix of fields within the institution; or, 2) as has been suggested (Barsoum 2017; Buckner 2013; Faek and Lynch, 2015; Krafft and Alawode 2018) - though not previously tested - different institutions may admit students with different scores to study in the same field. This analysis strongly supports the latter explanation.

Buckner argues that, in Egypt, there are "two distinct logics" governing entry to "two separate sectors" - public and private institutions (2013: 549). Access to public universities depends on a "meritocracy" - the score on the secondary school leaving exam. Access to private universities is based on market forces. The current analysis supports the roles of merit (or, more properly, scores) and market forces, but suggests a slightly different conclusion. Although secondary scores are critical for access to prestigious faculties in the public sector and wealth is certainly necessary for accessing the private sector, these findings suggest that universities and higher institutes, both public and private, form a unified system within which entry to a particular track and sector is governed in the first instance by a student's secondary leaving exam score and only secondarily by the student's family's ability to pay for private education.

If a student gets a high score, s/he can study the field s/he wants in public universities irrespective of family wealth. If, however, the student gets a low score, but wants to study a specific field, then family wealth becomes an important factor. If s/he has the ability to pay for her/his studies, then s/he will be able to attend a private university or private higher institute and study the field s/he wants. If s/he is not able to pay, then s/he might be able to study that field at a public higher institute, or must accept to study at university a field according to the score s/he achieved.

\section{References}

Abdallah, M., \& Langsten, R. (2016). Gender Distribution in Undergraduate Fields of Study: An Empirical Investigation Across Four Time Periods in Egypt.

International E-Journal of Advances in Education, 2(6), 404-41 17.

Akplu, H. F. (2016). Private Participation in Higher Education in sub-Saharan Africa: Ghana's Experience. International Higher Education, (86), $20-22$.

Al-Ahram. (1962, 25 July 1962). Abdel Nasser Yoelen Maganit El Taaleem Fi Jamiaa Marahloh [Abdel Nasser Declares Free Education at All Levels]. Al-Ahram.

Altbach, P. G., Reisberg, L., \& Rumbley, L. E. (Eds.). (2009). Trends in Global Higher Education: Tracking an Academic Revolution. Paris: UNESCO.

Antoninis, M. (2001). The Vocational School Fallacy Revisited: Technical Secondary Schools in Egypt, European University Institute Working Papers. Robert Schumann Centre for Advanced Studies, Mediterranean Programme Series. http://www.iue.it/RSCAS/WP-Texts/o1_22.pdf.

Arabsheibani, G. (1988). Educational Choice and Achievement: The Case of Secondary Schools in the Arab Republic of Egypt. Higher Education, 17(6), 637-646. 
Arum, R., Gamoran, A., \& Shavit, Y. (2007). Chapter 1. More Inclusion than Diversion: Expansion, differentiation, and market structure in Higher Education. In Y. Shavit, R. Arum \& A. Gamoran (Eds.), Stratification in Higher Education: A comparative study. Stanford CA: Stanford University Press.

Assaad, R. (2010). Equality for All? Egypt's Free Public Higher Education Policy Breeds Inequality of Opportunity. Cairo: Economic Research Forum.

Assaad, R., Badawy, E., \& Krafft, C. (2016). Pedogogy, Accountability, and Perceptions of Quality by Type of Higher Education in Egypt and Jordan. Comparative Education Review, 60(4), 746-775.

Barsoum, G. (2014). Aligning Incentives to Reforming Higher Education in Egypt: The Role of Private Institutions. Cairo: Economic Research Forum.

Barsoum, G. (2017). The Allure of 'Easy': Reflections on the Learning Experience in Private Higher Education Institutes in Egypt. Compare, 47(1), 105-117.

Bernasconi, A. (2010). Chile's Dominant Private Higher Education. ASHE Higher Education Report, 36(3), 23-35.

Blossfeld, H.-P., \& Shavit, Y. (1993). Persisting Barriers: Changes in Educational Opportunities in Thirteen Countries. In Y. Shavit \& H.-P. Blossfeld (Eds.), Persistent Inequality: Changing Educational Attainment in Thirteen Countries (pp. 122). Boulder, CO: Westview Press.

Brennan, J., \& Naidoo, R. (2008). Higher Education and the Achievement (And/or Prevention) of Equity and Social Justice. Higher Education, 56(3), 287-302.

Buckner, E. (2013). Access to Higher Education in Egypt: Examining Trends by University Sector. Comparative Education Review, 57(3), 527-552.

CAPMAS. (2013). Statistical Yearbook. Cairo: Central Agency for Public Mobilization and Statistics.

Carpentier, V. (2012). Public-Private Substitution in Higher Education: Has CostSharing Gone Too Far? Higher Education Quarterly, 66(4), 363-390.

Chivore, B. R. S. (2006). Private Higher Education in Zimbabwe. In N. V. Varghese (Ed.), Growth and Expansion of Private Higher Education in Africa (pp. 23 1-248). Paris: International Institute for Educational Planning.

Cloete, N. and Moja, T. (2005). Transformation Tensions in Higher Education: Equity, Efficiency, and Development. Social Research, 72(3), 693-722.

Cupito, E., \& Langsten, R. (2011). Inclusiveness in higher education in Egypt. Higher Education, 62(2), 183-187.

Elgeziri, M., \& Langsten, R. (2010). Equity and Decision Making in the Transition to University Education in Egypt. Paper presented at the Conference on: University Governance and Autonomy in the Changing Landscape of Higher Education in the Arab World, Beirut, 10-11 January 2010, Retrieved 17 January 2016, from: http://arabhighered.org/wp-content/uploads/2015/11/Elgeziri-and-LangstenEquity.pdf.

Faek, R., \& Lynch, S. (2015). Are Private Universities Worth the Money? Al-Fanar, 22 Jan.2015. Retrieved 1 Feb. 2015. From: http://www.alfanarmedia.org/2015/01/private-universities-worth-money/.

Fahim, Y., \& Sami, N. (2011). Adequacy, Efficiency and Equity of Higher Education Financing: The Case of Egypt. Prospects, 41, 47-67.

Farag, E. (2007). Egypt. In J. J. F. Forest \& P. G. Altbach (Eds.), International Handbook of Higher Education (pp. 693-709). Dordrecht, Netherlands: Springer.

Filmer, D., \& Pritchett, L. H. (2001). Estimating Wealth Effects Without Expenditure Data--Or Tears: An Application to Educational Enrollments in States of India. Demography, 38(1), 115-132. 
Geiger, R. (1985). The Private Alternative in Higher Education. European Journal of Education, 20(4), 385-398.

Ginsburg, M., \& Megahed, N. (2011). Globalization and the Reform of Faculties of Education in Egypt: The Roles of Individual and Organizational, National and International Actors. Education Policy Analysis Archives, 19(15), 1-25.

Halsey, A. H. (1972). Educational Priority - Volume 1: E.P.A. Problems and Policies. London: Her Majesty's Stationery Office.

Halsey, A. H., Heath, A. F., \& Ridge, J. M. (1980). Origins and Destinations: Family, Class, and Education in Modern Britain. Oxford: Clarendon Press.

Jackson, M., \& Buckner, E. (2016). Opportunity without Equity: Educational Inequality and Constitutional Protections in Egypt. Sociological Science, 3, 730-756.

Krafft, C., \& Alawode, H. (2018). Inequality of Opportunity in Higher Education in the Middle East and North Africa. International Journal of Educational Development, 62, 234-244.

Krafft, C., Elbadawy, A., \& Assaad, R. (2013). Access within the Higher Education System: Evidence for More Inequality of Opportunity In A. Elbadawy (Ed.), Is There Equality of Opportunity under Free Higher Education in Egypt? (Arabic) (pp. 101-134). New York: Population Council.

Kwiek, M. (Ed.). (2016). From growth to decline? Demand-absorbing private higher education when demand is over. Cambridge, England: Chandos Publishing.

Langsten, R. (2015). Effectively Maintained Inequality: Access to Higher Education in Egypt. In R. T. Teranishi, L. B. Pazich, M. Knobel \& W. R. Allen (Eds.), Mitigating Inequality: Higher Education Research, Policy, and Practice in an Era of Massification and Stratification (Vol. 11, pp. 35-51). Bingley, UK: EmeraldInsight.

Levy, D. C. (2006). The Unanticipated Explosion: Private Higher Education's Global Surge. Comparative Education Review, 50(2), 217-240.

Levy, D. C. (2010). The Global Growth of Private Higher Education. ASHE Higher Education Report, 36(3), 121-133.

Levy, D. C. (2013). The Decline of Private Higher Education. Higher Education Policy, 26(1), 26-42.

Lucas, S. R. (2001). Effectively Maintained Inequality: Education Transitions, Track Mobility, and Social Background Effects. American Journal of Sociology, 106(6), $1642-1690$.

McCowan, T. (2004). The Growth of Private Higher Education in Brazil: Implications for Equity and Quality. Journal of Education Policy, 19(4), 453-472.

McCowan, T. (2007). Expansion without equity: An analysis of current policy on access to higher education in Brazil. Higher Education, 53(5), 579-598.

Megahed, N. (2002). Secondary Education Reforms in Egypt: Rectifying Inequality of Educational and Employment Opportunities. In C. Acedo (Ed.), Case Studies in Secondary Education Reform. Washington, DC: American Institutes for Research.

MoE (Ministry of Education). (2014). Strategic Plan for Pre-University Education: 20142030. Cairo: Ministry of Education.

MoHE (Ministry of Higher Education -- Strategic Planning Unit). (n.d.). Higher Education in Egypt: Country Background Report - Summary. Cairo: Ministry of Higher Education.

MoHE (Ministry of Higher Education). (2007). Guide to Higher Education in Egypt. Cairo: Ministry of Higher Education.

Morley, L., Leach, F. et al. (2010). Widening Participation in Higher Education in Ghana and Tanzania: Developing an Equity Scorecard. An ESRC/DEID Poverty

Reduction Programme Research Project. 
Morley, L. (2014). Inside African Private Higher Education. In D. Araya and P. Marber. (Eds.), Higher education in the global age: policy, practice and promise in emerging societies. New York, Routledge 140-159.

OECD. (2015). Schools for Skills - A New Learning Agenda for Egypt. Paris: OECD.

Orlans, H. (1992). Affirmative Action in Higher Education. Annals of the American Academy of Political and Social Science, 523, 144-158.

Patrinos, H. A. (1990). The Privatization of Higher Education in Colombia: Effects on Quality and Equity. Higher Education, 20(2), 161-173.

Population Council. (2010). The Survey of Young People in Egypt: Final Report. Cairo: Population Council, Egypt.

Population Council. (2015). Panel Survey of Young People in Egypt (SYPE) 2014. Generating Evidence for Policy, Programs, and Research. R. Roushdy and M. Sieverding. (Eds.), Cairo: Population Council, Egypt.

Quddus, M., \& Rashid, S. (2000). The Worldwide Movement in Private Universities: Revolutionary Growth in Post-Secondary Higher Education. American Journal of Economics and Sociology, 59(3), 487-516.

Radwan, M. M., Sharaf, R. S., \& Ibrahim, D. K. (2012). Providing Quality Mass Higher Education, the Egyptian Experience. Paper presented at the Conference on Attaining and Sustaining Mass Higher Education, Paris, 17-19 September 2012. Retrieved 4 April 2018. From https://www.researchgate.net/publication/282611801_Providing_Quality_Mas s_Higher_Education_the_Egyptian_Experience.

Raftery, A. E., \& Hout, M. (1993). Maximally Maintained Inequality: Expansion, Reform, and Opportunity in Irish Education, 1921-75. Sociology of Education, 66(1), 41-62.

Rasmussen, C. J. (2006). Effective Cost-Sharing Models in Higher Education: Insights from Low-Income Students in Australian Universities. Higher Education, 51, 125.

Richards, A. (1992). Higher Education in Egypt. Washington DC, The World Bank.

Schendel, M., \& McCowan, T. (2016). Expanding higher education systems in low- and middle-income countries: the challenges of equity and quality. Higher Education, $72(4), 407-411$.

Shann, M. H. (1992). The Reform of Higher Education in Egypt. Higher Education, 24(2), 225-246.

Shrivastava, M., \& Shrivastava, S. (2014). Political economy of higher education: comparing South Africa to trends in the world. Higher Education, 67(6), 809-822.

Slantcheva-Durst, S. (2010). Private Higher Education in Bulgaria: Making a Difference. ASHE Higher Education Report, 36(3), 37-50.

Szyliowicz, J. S. (1973). Education and Modernization in the Middle East. Ithaca, Cornell University Press.

Teixeira, P., \& Amaral, A. (2001). Private Higher Education and Diversity: An Exploratory Survey. Higher Education Quarterly, 55(4), 359-395.

Tieban, N., \& Wolbers, M. H. J. (2010). Transition to Post-Secondary and Tertiary Education in The Netherlands: A Trend Analysis of Unconditional and Conditional Socio-Economics Background Effects. Higher Education, 60, 85-100.

UNESCO (2017). Six Ways to Ensure Higher Education Leaves No One Behind. Paris, UNESCO.

Varghese, N. V. (Ed.). (2006). Growth and Expansion of Private Higher Education in Africa. Paris: International Institute for Educational Planning.

Varghese, N. V., \& Puttman, V. (2011). Trends in diversification of post-secondary education. Paris: International Institute for Educational Policy. 
World Bank. (1994). Higher Education: The Lessons of Experience. Washington, D.C.: The World Bank.

World Bank. (2010). Higher Education in Egypt. Washington, DC: The World Bank.

\section{About the Authors}

Fatma Abdelkhalek is a PhD candidate at the Institute of Mathematics of Budapest University of Technology and Economics and holds a demonstrator position at the Faculty of Commerce of Assiut University in Egypt. She worked as an applied statistician and data analyst at the Social Research Center of American University in Cairo for several years. Her current research uses structural equation modeling and partial least squares among other statistical techniques to examine issues such as education, community schools, and child mortality.

Ray Langsten is Senior Research Fellow at the Social Research Center of the American University in Cairo. He has a $\mathrm{PhD}$ from the University of Michigan in Sociology/Demography. His current research focuses on education, mainly the measurement issues related to the sustainable development goals, as well as a variety of topics dealing with education in Egypt. 


\section{Appendix A}

\section{Tansik System}

In Egypt, joining higher education institutions is a multi-step process. When students take the secondary leaving exam (Thanaweya Amma [TA], they are given a unique ID. After the results of TA are announced, the Ministry of Higher Education and Scientific Research (MoHE) sets the minimum scores that are acceptable for each program in both public and private higher education institutions. These minimums are set based on the number of places available in each program and the distribution of scores of the TA. These scores differ by the general secondary section where a student has studied: scientific or arts.

The process of placing students is known as "Tansik". It has three sequential stages during which students are allocated to a higher education program. The first stage for allocating students includes the faculties requiring the highest minimum scores: that is, the most prestigious faculties (medicine, engineering, media). Once the "tansik" results for the first stage are announced, students use their ID to gain access to the online application called the "desires/preferences form". At each stage, students with a TA score that matches or exceeds the minimum acceptable score in the stage, are able, through an online system ${ }^{16}$, to enter up to 60 choices in order of their preference. They can change their desires, if they want, only until the deadline of the stage. If all the places in a particular program are filled in the first stage, that program does not move to the second stage. If some places remain unfilled, the minimum score of entering the program is reduced by a small amount to fill the remaining places. For example if the minimum score for entering engineering at the first stage is 95. After the first stage is completed, if there are empty places in engineering the minimum score may decrease to, say, 94.3. The few remaining places will be filled at the second stage.

When the first stage is completed, the minimum scores for the second stage are announced. The second stage includes less prestigious faculties (for example, law, arts, and commerce) that require lower scores than those of the first stage. Students meeting the minimum score of the second stage go to the online system to enter their preferences. Once the second stage is completed, the third stage starts and requires just passing the TA. Then all the remaining students apply through the online system. Students use their ID to receive the results of their placement.

The "tansik" office allocates students to programs based on the minimum entry score required and the student's preference. If a student's score is adequate for her/his first preference, $\mathrm{s} /$ he will be placed in that program, even if that score would qualify for a much more prestigious program. For example, if a student got a score of 99 and her/his first choice is the faculty of commerce, the "tansik" office will assign her/him to commerce even though the minimum score to enter the faculty of commerce is 80 . On the other hand, if a student got a score of 80 and her/his first choice is medicine the "tansik" office will place her/him in the second or third or lower choice of that student, whichever is a faculty that accepts a score of 80 . Some students, especially those with low scores, may be allocated to a program that corresponds to none of their preferences (World Bank 2010).

The following table (A1) shows the minimum score announced by the MoHE for two fields of study for different higher education institutions according to tansik 2017. Of the two fields chosen, one represents a prestigious field "Engineering/IT" and the other is less prestigious "Commerce/Business". It is clear that studying a prestigious field in a public university requires the highest score, while study of the same field in a private university or public or private higher institute is possible with a much lower score. In addition the less prestigious field requires lower scores than the prestigious field.

${ }^{16}$ https://tansik.egypt.gov.eg/application/ 
In sum, none of the Egyptian universities are "selective", in the way that American universities, for example, may be selective. Rather, in Egypt, faculties are selective. All universities accept anyone who passes the TA with a minimum score of 70 . For example, at Cairo University, engineering requires a score of 94.6 (388 out of 410 points). But, you can enter the faculty of commerce with a score of just 76.3 (313 out of 4.10 points) or the faculty of law with 71.1 (292 out of 410 points).

Table A1.

Minimum score for studying the same field in different higher education tracks and sectors.

\begin{tabular}{cccccc}
$\begin{array}{c}\text { Field of } \\
\text { Study }\end{array}$ & $\begin{array}{c}\text { Secondary } \\
\text { Section }\end{array}$ & \multicolumn{2}{c}{ University } & \multicolumn{2}{c}{$\begin{array}{c}\text { Higher } \\
\text { Institute }\end{array}$} \\
& Public & Private & Public & Private \\
\hline Engineering & Arts & $--^{-}$ & -- & -- & -- \\
$/$IT & Scientific & 95.8 & 80.0 & 78.5 & 80.0 \\
\hline Commerce/ & Arts & 76.3 & 55.0 & 57.0 & 50.0 \\
Business & Scientific & 81.4 & 50.0 & 60.0 & 50.0
\end{tabular}

+ Students in the Arts section of general secondary are not eligible to enter scientific faculties such as medicine, agriculture, and engineering/IT.

Source: Ministry of Higher Education announcement "Tansik 2017”. 


\section{Appendix B}

Table B 1.

Illustration of Mean Score Difference in Universities Offering Different Fields.

\begin{tabular}{cccc}
\multicolumn{3}{c}{ University } \\
\cline { 2 - 4 } & \multicolumn{2}{c}{ Public } & \multicolumn{2}{c}{ Private } \\
\hline Score & Student & Score & Students \\
\hline
\end{tabular}

Field

$\begin{array}{rcccc}\text { A - High } & 95 & 50 & 95 & - \\ \text { B- Middle } & 85 & 50 & 85 & 50 \\ \text { C- Low } & 70 & -- & 70 & 50 \\ \text { Mean } & & & & \\ \text { Score } & 90 & & 77.5 & \end{array}$

Table B2.

Illustration of Mean Score Difference in Universities Accepting Different Scores in the Same Field.

\begin{tabular}{rcccc} 
& \multicolumn{4}{c}{ University } \\
\cline { 2 - 5 } Public & \multicolumn{2}{c}{ Private } \\
\hline Score & Student & Score & Students \\
\hline A - High & 95 & 20 & 90 & 20 \\
B - Middle & 85 & 35 & 80 & 35 \\
C- Low & 70 & 45 & 60 & 45 \\
Mean & & & & \\
Score & 80.25 & & 73 &
\end{tabular}

